\title{
Donato Ndongo e o exílio literário
}

\author{
Cátia Miriam Costa*
}

\begin{abstract}
Resumo
Donato Ndongo, escritor equatoguineense, retrata a situação no seu país, uma conjuntura ditatorial tornada estrutura política, social e cultural, em que o medo domina a sociedade e impede os intelectuais deste país de expressarem livremente o seu pensamento. Para compreender a obra do autor, urge entender a problemática subjacente à produção artística no seu país de origem e às condições de recepção no país onde escreve e dos públicos que poderão aceder ao seu trabalho. Estas assumem particular importância, quando o autor se vê forçado a publicar no exílio, no país outrora potência colonizadora, a Espanha, e a trabalhar para públicos abrangentes, inseridos em sistemas culturais distantes do equatoguinneense, portanto, desconhecedores das especificidades aí existentes.
\end{abstract}

\section{Palavras-chave}

Donato Ndongo. Exílio literário. Produção artística.

La utopía no ha muerto, tenemos que conseguir lo que ahora parece imposible. Aunque como escritores no estaremos obligados a llevar a la práctica nuestras ensoñaciones, al carecer de todo poder tangible, sí tenemos el poder de anticipación, el poder de proponer, el poder de transformar, el poder de la palabra, vehículo de toda acción. (NDONGO, 2010, p. 36).

\section{Introdução}

Despite independence in 1968 we have never experienced a democratic regime. We have never known peace, well being, or economic development. Donato Ndongo (UGARTE, 2004, p. 218).

Donato Ndongo, escritor equatoguineense, descreve assim a situação no seu país, uma conjuntura ditatorial tornada estrutura política, social e cultural, em que o medo domina a sociedade e impede os intelectuais deste país de expressarem livremente o seu pensamento. Em 43 anos de independência, nunca se verificou a mais leve tolerância para com o livre pensamento, o que levou a que muitos tivessem saído do seu país ou permanecido no estrangeiro. Donato Ndongo pertence a essa

\footnotetext{
* Docente da Universidade de Évora e Fundação para a Ciência e a Tecnologia. E-mail: catia_miriam1@hotmail.com.
} 
geração que teve de sair ou ficar de fora das suas fronteiras natais, a essa estirpe de intelectuais condenada ao exílio. Actualmente, desenham-se novas propostas intelectuais neste país, embora, todas elas lutando para poder manter alguma liberdade na sua expressão e que, mesmo assim, podem ser condenadas ao abandono da sua terra ${ }^{1}$. Considerado como o "pai" da literatura da Guiné Equatorial tem mantido uma qualidade artística na sua produção literária indubitável, sem nunca abandonar um papel de intervenção social, defendendo, desde sempre, a importância da arte na projeção da transformação social. Em tempos em que, cada vez mais, se discute o papel da arte na sociedade, Donato Ndongo pode ser tido como um exemplo a estudar pela força com que tem tentado intervir nas sociedades onde exerce a sua arte.

Para compreender a obra do autor, urge entender a problemática subjacente à produção artística no seu país de origem e às condições de recepção no país onde escreve e dos públicos que poderão aceder ao seu trabalho. Esta questão assume particular importância, quando o autor se vê forçado a publicar no exílio, no país outrora potência colonizadora, a Espanha, e a trabalhar para públicos abrangentes, inseridos em sistemas culturais distantes do equatoguinneense, portanto, desconhecedores das especificidades aí existentes. As primeiras edições de todos os seus livros foram feitas em Espanha, apesar de hoje contar com a publicação de traduções das suas obras em francês (La tenèbre de ta memoire, Paris, Editions Galimard), em 2004, em inglês (Shadows of your black memory, Chicago, Swan Isle Press), em 2007, e em italiano (Il metro, Edizione Goree), em 2010. Se o espanhol foi a sua língua de eleição, por ser igualmente a língua em que foi educado, tem vindo a afirmar repetidas vezes que pretende alcançar um público diversificado, ou seja, todos aqueles que se poderão interessar pela sua obra, independentemente da sua origem ou cultura.

Aliás, a questão linguística, como veremos adiante, é das mais exploradas na sua obra, procurando simbologias, demonstrando paradoxos e, sobretudo, mostrando ao mundo a complexidade deste factor em países como a Guiné Equatorial. Colonizada por Espanha, a Guiné Equatorial, e consequentemente os seus intelectuais, vê-se excluída dos grandes grupos linguísticos europeus presentes em África, como a francofonia, a anglofonia ou a lusofonia, o que de certa forma também the tem cerceado o contacto com os intelectuais dos países vizinhos. No contexto do sul do Sara, é o único país a ter como língua oficial o espanhol e a propor uma expressão afro-hispânica no quadro da literatura escrita nesta língua. Ao seu isolamento linguístico, acrescentam-se outros, fruto da sua transição do regime colonial para a independência. A Guiné Equatorial torna-se independente em 1968, libertando-se do jugo de um país governado por uma ditadura que amordaçava os seus próprios intelectuais na metrópole e que, curiosamente, acede a fazer não só a transição para a autodeterminação política, como introduz o conceito de eleições livres, aquando deste processo. O resultado foi o nascimento de um país livre, liderado pelo vencedor das

\footnotetext{
${ }^{1}$ Exemplo flagrante e recente dessa situação é o caso do escritor Juan Tomás Ávila Laurel que sempre viveu em Malabo (Bioko, Guiné Equatorial) e se viu forçado a abandonar o seu país, enquanto decorria a sua greve de fome em protesto pela situação política e social no seu país, começada no dia 12 de fevereiro de 2011 e terminada uma semana depois, já em Barcelona (Catalunha, Espanha).
} 
eleições, Francisco Macías. Em Espanha, a Guiné Equatorial tornava-se "matéria reservada" e assim permaneceu até à queda de Francisco Franco em 1975. Na Guiné Equatorial, iniciava-se um processo que, começando por ser uma primavera política, com uma constituição democrática, consagrando a separação de poderes e a realização de eleições livres periódicas, se transforma numa dura ditadura, sob o pretexto de terem sido preparados uma conspiração e um golpe, apenas cinco meses depois da autodeterminação. O presidente manda prender todos os líderes partidários, torna o seu partido único (Partido Nacional dos Trabalhadores), decreta a "Revolução Guineense" e começa uma perseguição implacável aos intelectuais equatoguineenses, controlando todo o espaço público, despolitizando todos os possíveis actores sociais, calando-se os que ainda tinham voz, naquilo a que Donato Ndongo chamou "os anos do silêncio".

A ratificação da constituição revolucionária em 1973, uma antiga metrópole emudecida, apesar de ter o maior número de exilados do jovem país a viver aí, e os equilíbrios conseguidos pelo ditador através da procura de novos alinhamentos antiimperalistas e anti-colonialistas, em nome dos quais era preciso africanizar todos os espaços públicos, começando pelo cultural, constituíram factor fulcral no êxodo intelectual que se verificou. Surge, pois, um discurso exilado de resistência cultural, oferecendo propostas alternativas e denunciando os excessos do regime e o trauma histórico, social e cultural em que vivia o país. O que estes intelectuais exilados, entre os quais se conta Donato Ndongo, propunham era um diálogo pela lembrança de todo um povo contrapondo o seu discurso àquilo que Ciriaco Bokesa Napo, escritor equatoguineense, denominou como a apropriação da realidade por parte do regime de Macías e a imposição de um monólogo político e cultural. Contudo, esse discurso de resistência caracterizava-se por ser periférico, tanto à sociedade equatoguineense (pelo factor exílio) como à sociedade espanhola (a viver a reserva destas matérias), marginal, sem conseguir penetrar nos grandes meios de difusão social e cultural e, sobretudo, precário pelas deficitárias condições que os exilados tinham de ultrapassar para fazer ouvir a sua voz.

Em 1979, dá-se um novo golpe de estado que levou ao poder o ainda presidente Teodoro Obiang que derrubou o seu próprio tio. Tendo feito treino militar em Espanha, foi aceite como o protagonista da mudança, apesar dos intelectuais no exílio terem mostrado algumas reservas. Fundou o Partido Democrático da Guiné Equatorial e prometeu um regime multipartidário, em que ainda hoje é proibido promover encontros ou disseminar informação de carácter político. No entanto, a situação pouco ou nada mudou, com excepção para a massiva exploração petrolífera que, até hoje, não beneficiou a população em geral e que trouxe novos protagonistas, abrindo o país às multinacionais petrolíferas. A pressão externa nos anos noventa do século XX traz alguma esperança e para contrariar $o$ isolamento do país, Obiang faz algumas cedências, em seguida retiradas, devido a apoios que recebe dos Estados Unidos da América por causa da extracção petrolífera e de França que pretendia ver tornado o francês língua oficial do país. A esta nova realidade, Ndongo denominou "política do petróleo" que tem vigorado até hoje com graves consequências para o povo equatoguineense (UGARTE, 2004, p. 222). Nestas condições, a vida intelectual do país tem sido diminuta, dependendo sempre dos influxos externos, seja através da 
cooperação dos centros culturais, seja através da publicação no exterior, visto tratarse de um país sem imprensa, sem livrarias, sem editoras e com muito poucos leitores. É à luz desta realidade que Donato Ndongo e todos os outros autores equatoguineenses produzem a sua obra numa expressa vontade de contrariar as adversidades.

\section{Génese de uma nova literatura: a expressão equatoguineense}

[...] should we create something new, should we seek to be original in the western sense, or should our main contribution to culture be the recreation of our traditions and thereby assert our identity? Donato Ndongo (UGARTE, 2004, p. 230).

O aparecimento de uma literatura com características próprias na Guiné Equatorial é tão recente que a sua existência, enquanto expressão cultural específica, ainda considerada como uma literatura menor, subsistindo num profundo isolamento linguístico e cultural que a faz distanciar-se um pouco das suas congéneres vizinhas e, também, dos fenómenos literários dentro do mundo hispânico, dos quais parece estar apartada por profunda desinformação. Na verdade, o seu estudo é recente e o seu consumo pelo público leitor é extremamente baixo, o que não facilita nem a sua afirmação no mercado editorial nem enquanto objecto de estudo académico. Na verdade, a ausência total de uma política de apoio à divulgação desta literatura, que apenas encontra algum amparo na cooperação espanhola, tem tornado qualquer tentativa de divulgação literária num projecto titânico para cada um dos autores. Quando Donato Ndongo classifica esta literatura, quase em fase emergente, como afro-hispânica, fá-lo numa tentativa de conciliar as heranças que poderão condicionar a própria produção artística, o facto de uma cultura banto se ter encontrado com a cultura espanhola e a partir daí ter produzido uma nova realidade, própria e única. Outro aspecto a considerar é que o ensino literário na Guiné Equatorial, a par do restante ensino, é bastante deficitário, não sendo conhecidos os seus próprios autores nem os dos países vizinhos, apenas alguma literatura espanhola faz parte do curriculum escolar.

A ausência de uma história literária com raízes mais longínquas, como acontece noutros países africanos em que a literatura foi uma arma ao serviço da luta anticolonial, leva a que a expressão literária equatoguineense apareça aos olhos dos críticos, dos estudiosos e do público como algo extremamente recente e ainda com poucos atributos próprios, essenciais para se considerar o surgimento de uma nova literatura. Apesar de o colonialismo espanhol ter apresentado as características gerais dos colonialismos europeus em África e das suas consequências pouco diferirem, a verdade é que, à época da independência, o conjunto de intelectuais formados e com capacidade de participar na sociedade civil era extremamente diminuto. Assim, as primeiras manifestações com carácter de continuidade e já demonstrando características de uma corrente literária própria nascem, em parte, no exílio, grupo em se insere o autor aqui apresentado, no próprio país, mas em número muito restrito. Estamos a falar no total de um universo de aproximadamente uma dezena de autores 
que começa a publicar em meados da década de setenta do século XX. Antes dessa época, existem pouquíssimos registos literários, mesmo abarcando toda a produção, incluindo a recolha de tradição oral.

Esta situação conduziu a que a recepção literária de toda a novidade inerente a estas novas propostas em espanhol não tenha vindo a ser fácil. A ausência de programas escolares e universitários em seu torno, uma inexistência de espaço no mundo editorial e uma recepção desinteressada nos meios de comunicação social e entre os intelectuais mais vinculados às literaturas hispânicas constituem, ainda hoje, dificuldades enfrentadas por um conjunto de autores que procura afirmar esta expressão como específica. Apesar disso, os autores equatoguineenses já são estudados em vários países, sobretudo, devido ao empenho de alguns investigadores que têm explorado o tema. Entre os autores estudados, Donato Ndongo ocupa, de facto, um lugar de destaque, sendo aquele que mais atenção tem recebido. Como refere M'Bare N'Gom ( $N^{\prime} G O M, 2010$, p. 23), até meados dos anos noventa do século $\mathrm{XX}$, a literatura africana de expressão espanhola foi a grande ausente do debate em torno das línguas transcontinentais em geral como, também, do debate em torno das literaturas hispânicas. Assim, viu-se num profundo isolamento, apenas interrompido pelas actividades dos seus próprios escritores e pela dedicação de alguns académicos investigadores. Parecia que existia algo que a distanciava de todos os processos de formação das literaturas africanas, fortemente ligadas ao uso de uma língua transterritorial, fruto de um sistema de ensino em língua alienígena, a do colonizador, e condicionadas pela imprensa colonial e pelos meios de produção impressa em geral (por exemplo, das missões religiosas). Na verdade, na Guiné Equatorial, mesmo no tempo do colonialismo, todos esses meios escasseavam, destacando-se apenas a revista claretiana, La Guinea Española, dominada pelos missionários, na sua maioria de origem espanhola. Mesmo os jovens que iam estudar para a capital espanhola, Madrid, aí não encontravam eco das ideias africanistas, então, em voga. Não existiam aí mais estudantes de outras proveniências africanas e, igualmente, as actividades intelectuais eram controladas por uma censura ativa que cerceava a maioria das atividades consideradas fora do consignado pela ideologia do Estado. Enquanto nas outras metrópoles coloniais circulavam ideias de resistência anti-colonial e de novos conceitos estéticos e ideológicos como a negritude e o pan-africanismo, em Espanha, os estudantes africanos continuavam a ser olhados com curiosidade e estranheza. 0 primeiro romance verdadeiramente equatoguineense surge apenas em 1953, com Cuando los combes luchaban, de Leoncio Evita Enoy, ainda com fortes marcas etnográficas, reportando o leitor a descrições de tradições e ritos, tendo, contudo, a inovação de usar a língua do colonizador para fixar a memória histórica e cultural do colonizado, mas ainda sem um grande rasgo criativo que pudesse já marcar o nascimento de uma narrativa específica, reflexiva de um espaço determinado.

Essa literatura equatoguineense virá a nascer mais tarde, quando o processo de apropriação da escrita numa língua, outrora outra, gera uma acomodação desse mesmo idioma, enriquecendo-o e transformando-o por préstimos locais e por modos de falar típicos de uma certa geografia. A circulação de saberes e registos estilísticos da literatura escrita e da literatura oral permitiu a construção de um novo espaço de expressão e de um produto literário único, fruto de uma determinada conjugação 
cultural. Assim, percebe-se a afirmação de Donato Ndongo quando refere a força vital que cada elemento da natureza tem para o africano e como essa "força" é incorporada na criação artística e está presente no património cultural destes povos. Deste modo, o escritor acaba por passar esse sentimento à sua criação literária que, podendo soar a realismo mágico" não o é, por constituir parte do cerne da cultura africana e equatoguineense, neste caso. É buscando o equilíbrio entre o revelar da tradição, o honrar da memória e a criação que melhores obras poderão surgir, porque seriam mais fiéis ao seu sistema cultural de partida (UGARTE, 2004, p. 227-228). No entanto, não se pense que estes elementos ficam consignados ao conteúdo das obras, outras estratégias estilísticas são usadas no sentido de reforçar a mensagem que intrinsecamente se quer fazer passar. Exemplos disso são a repetição de expressões que remontam para uma mesma realidade, a incidência sobre os aspectos morais, renovando o mesmo assunto com palavras diferentes, a inserção de pequenos relatos no meio da narrativa com o sentido de criar asserções morais que façam sentido para as personagens e para o leitor, a localização no tempo que parece não ter medida cronológica e antes se fixar em acontecimentos importantes para a vida da comunidade ou da família, o trazer o passado para o presente através dos relatos tradicionais dos clãs ou tribos, atribuindo-lhes uma explicação para a existência do próprio presente. Todos estes artifícios próprios do artesão das palavras que parecem tão simples aparecem-nos, na maioria dos casos, integrados em construções narrativas cujos recursos gerais são os ocidentais, o que é extremamente óbvio no caso dos romances, em que a estrutura que os enforma é idêntica à de qualquer autor de cultura ocidental, mas que é, em simultâneo, temperada por estes elementos que podem provocar o distanciamento da narrativa face aos padrões mais habituais vigentes no sistema literário ocidental.

Todavia, todo este trabalho criativo fica ameaçado dados os obstáculos que se têm colocado a uma literatura ainda nascente. A Antología de la literatura guinenana, de Donato Ndongo aparece, em 1984, quase como um acto fundador de uma nova expressão literária, encurralada na falta de reconhecimento do artista, na inexistência de círculos literários e na ausência de qualquer meio vocacionado directamente para a sua difusão. Foi de tal maneira inovadora esta obra que quase passou despercebida entre os meios intelectuais espanhóis que nela não viram o facto revelador que não era mais que o reconhecimento de uma nova literatura escrita em língua espanhola. Contudo, a situação actual ainda não é animadora e não se pense que estas dificuldades estão ultrapassadas, apenas vão sendo debeladas pelo esforço dos próprios autores que buscam as várias possibilidades para o verdadeiro reconhecimento da sua arte. Apesar de já ser estudada em várias cátedras, a literatura equatoguineense ainda sofre de constrangimentos que a ancoram numa situação de dependência face a uma série de elementos exteriores.

Gustau Nerin refere algumas dessas condicionantes que nos demonstram como a conjuntura em torno desta literatura ainda a pode colocar no lugar de uma "expressão literária menor" (Vide NERÍN, 2010, p. 299-305). Entre estas refere as baixas tiragens dos livros, em geral, publicados em Espanha, livros vendidos em número reduzido, afastamento desta literatura das grandes livrarias e das grandes superfícies comerciais, reduzindo o seu conjunto de leitores às pessoas directamente 
interessadas na Guiné Equatorial ou em literatura. Na Guiné Equatorial, a recepção das obras dos autores equatoguineenses seria ainda menor, devido ao sistema educativo e à já aludida falta de meios de produção, difusão e de comercialização das obras literárias. Nerin aponta, ainda, o dedo à ausência de uma crítica literária consequente que, pela falta de presença desta literatura nas estantes das bibliotecas e livrarias, acabou por consagrar por igual obras e autores com valor e outros com qualidade duvidosa, o que não ajudou à criação de um público leitor interessado pelo aspecto artístico da obra, como acontece com outras literaturas escritas ou não em espanhol. O impacto social, às vezes, pretendido pelo autor, sai menorizado por todas estas condicionantes, pois o índice de leitura fica sempre aquém daquilo que poderiam ser as possibilidades da obra se não estivesse restrita a públicos tão específicos, em que sobressaem os académicos e alguns africanistas. É à luz deste estado da arte que teremos de analisar a obra de Donato Ndongo, o seu papel pioneiro e a novidade artística proposta pela sua obra literária.

\section{Entre o cidadão escritor e o escritor cidadão}

Me confieso [...] un modesto seguidor de africanos ilustres como Kwame Nkrumah, Amilcar Cabral y Agostinho Neto, para quienes el anticolonialismo militante que indudablemente profesaron no llevaba aparejado el rechazo de las aportaciones esenciales de otras civilizaciones, como la técnica, la escritura y la lengua. (NDONGO, 2010, p. 23)

Donato Ndongo nasce em 1950, em Alén (Niefang, na Guiné Equatorial). Inicia a sua formação escolar ainda na sua terra natal, tendo seguido para o Colégio dos Missionários Claretianos em Niefang. Faz o ensino secundário em Bata (na parte continental da então Guiné Espanhola), tendo, depois, seguido para Espanha, mais propriamente para Valência onde termina este grau de ensino. Muito cedo, foi reconhecido o seu talento literário, tendo recebido o Prémio Nacional de Redação, convocado pela Delegação da Juventude para os estudantes do ensino secundário em Espanha, com um trabalho intitulado "O Futuro e os Jovens". A independência da Guiné Equatorial, em 1968, ocorre quando ainda estuda em Espanha. Um ano após a autodeterminação do seu país matricula-se na Escola Oficial de Periodismo de Barcelona e, em simultâneo, cursa História e Geografia na Universidade de Barcelona, vertentes do conhecimento que marcarão a sua carreira profissional e alargarão os seus horizontes enquanto escritor.

Licencia-se em jornalismo em 1972 e, no ano seguinte, publica a sua primeira ficção, com o título El sueño, na revista Papeles de Son Armadans, dirigida por Camilo José Cela. Em 1974, obtém a licenciatura em Geografia e história, especializando-se em História Contemporânea e tem o seu primeiro grande desafio, enquanto jornalista, tendo sido designado para cobrir a "Revolução dos cravos" em Portugal para a revista espanhola Índice. Esse seu desempenho valerá um contrato fixo com a revista, na qual trabalhou até à sua extinção. Já com uma carreira sólida no jornalismo e escrevendo para vários títulos da imprensa espanhola, publica, em 1977, o seu primeiro livro, em Madrid, pela Editorial Cambio, intitulado História y tragédia de Guinea Ecuatorial. Sem 
recurso à ficção, põe a nu a grave situação vivida no seu país naquela época. Em paralelo, desenvolve actividades ligadas à história e à cultura africanas e, em 1984, publica um texto chave para a compreensão do fenómeno literário na Guiné Equatorial, também em Madrid, pela Editora Nacional, chamado Antología de la literatura guineana.

Regressa ao seu país em 1985, depois de ser nomeado director-adjunto do Centro Cultural Hispano-Guinenano, em Malabo (Guiné Equatorial). Em 1987, é designado correspondente da agência espanhola de notícias, EFE, e nesse mesmo ano publica o seu primeiro romance, Las tinieblas de tu memoria negra, primeira obra da trilogia, ainda inacabada, que pretende constituir uma reflexão ficcional sobre o percurso da Guiné Equatorial. $O$ ano seguinte é marcado por uma série de conferências nos Estados Unidos da América que representam um enorme passo na internacionalização da sua carreira e, igualmente, na tentativa de dar a conhecer ao mundo uma literatura, até então, consignada a um público muito reduzido a viver em Espanha. Em 1992, são alargadas as suas responsabilidades dentro da EFE e é nomeado Delegado para a África Central, cobrindo não só a Guiné Equatorial como os Camarões, o Gabão e São Tomé e Príncipe. Em 1995, devido ao cansaço acumulado e à tensão de um trabalho que, paulatinamente, parecia mais perigoso e stressante, decide regressar a Espanha. A sua experiência de vivência no seu próprio país termina nesse momento. Regressado a Espanha, publica, em 1997, Los poderes de la tempestad, segundo livro da trilogia sobre a Guiné Equatorial. Em 2000 é nomeado diretor do Centro de Estudios Africanos de la Universidad de Múrcia e, no mesmo ano, publica Literatura de Guinea Ecuatorial. Antología, em co-autoria com M'Bare N'Gom. O processo de internacionalização da sua obra segue não só com as inúmeras deslocações aos Estados Unidos da América como a outros países da Europa e, sobretudo, graças às traduções para o francês, o inglês e o italiano, anteriormente referidas.

Percorrendo a sua própria obra, é o autor que designa as grandes influências na sua escrita. A par de uma educação feita no sistema de ensino espanhol, logo projetando, todo o conhecimento e produção artística do mundo hispânico, Donato Ndongo declara-se herdeiro de grandes nomes da política e cultura africanas ou afroamericanas, destacando personalidades como Kwame Nkrumah, Amílcar Cabral, Agostinho Neto, Frantz Fanon e Chinua Achebe que teria sido o grande responsável pelo seu interesse na literatura, pois Donato Ndongo consegue rever-se naquilo que Achebe escreve e inicia um processo de pensamento sobre a sua própria cultura, no fundo, sobre a sua "diferença", enquanto africano vivendo na Europa (UGARTE, 2004, p. 233). Olhando para os intelectuais referidos pelo autor, como tendo influenciado a sua produção artística, é óbvia a preponderância das ideias que são fruto não só do questionamento das culturas africanas como do encontro entre tradição e modernidade, entre colonizador e colonizado, pois estes autores refletem exatamente essa aparente ambiguidade que também Ndongo transporta consigo. Deste modo, a asserção de Michael Ugarte que o declara como sendo "ocidental" de dois modos específicos: por ser originário da África Central/Ocidental e por ter algo de "europeu", pela sua educação e formação em Espanha, faz todo o sentido (UGARTE, 2004, p. 177). Sem desvirtuar a sua pertença africana, coloca aos olhos de todos a importância 
que a educação numa língua outra, a frequência do sistema de ensino na antiga metrópole e a convivência com o mundo intelectual ocidental tiveram na formação do seu próprio pensamento e obra. Aliás, essa ambivalência cultural teria sido a chave da sua própria criatividade e do curso que a sua obra tomou, senão vejamos, como poderia expressar melhor essa dicotomia na sua formação de outro modo que não fosse a conjugação de formas e conteúdos de origens diversos e, sobretudo, o uso de estruturas literárias consideradas de tradição ocidental, como o romance, e uma língua transterritorializada mas de origem europeia, o espanhol, para transmitir as derrotas e conquistas das comunidades africanas?

Joseph-Désiré Otabela menciona mesmo um compromisso que Ndongo teria com a situação dos povos africanos e que estaria materializado nos seus dois relatos curtos, nos seus três romances, na sua obra de carácter histórico e ensaístico e, até, na sua poesia, ainda inédita (OTABELA, 2010, p. 110). Ndongo, que começa pelo jornalismo, inicia a sua carreira na fiç̧ão com El sueño, um relato curto, inspirado num facto real que teria levado o autor a ter um pesadelo que decide registar e acrescentar, resultando no seu primeiro texto ficcional. Donato Ndongo lera uma notícia num jornal de Barcelona sobre trabalhadores ilegais que teriam chegado a Espanha com destino à França para uma espécie de trabalho quase escravo. Esse relato jornalístico causou tal impressão ao autor que este teve um pesadelo com essa situação, daí à escrita foi apenas um passo. Estava criado o primeiro texto em que a ficção vencera a realidade na escrita de Donato Ndongo.

Uma carreira literária promissora já se adivinhava e um estilo próprio parecia querer despertar. Já neste seu primeiro texto, Ndongo consegue coordenar um conteúdo, isto é, uma estória africana, com algumas características típicas das literaturas ocidentais e que se ligam à construção formal da narrativa, com as peripécias que passam as personagens, com os artifícios estilísticos chamados à narração, etc. Se o conteúdo é muitíssimo comprometido com uma mensagem social, no caso de El sueño, com o sofrimento da juventude africana em busca de estabilidade, de bem-estar material, de reivindicação do direito a uma personalidade cultural própria, a uma identidade e com a exposição de uma dialéctica que parecia permanecer, apesar da extinção do colonialismo na maioria dos países africanos, recriando situações próximas do relacionamento colonizador/colonizado, a sua forma bebe nas fontes artísticas ocidentais a maioria dos seus recursos. É continuando este registo que 14 anos mais tarde publica o seu primeiro romance, anteriormente referido, Las tinieblas de tu memoria negra, editando pelo meio um outro relato, denominado La travesía e focando o tráfico esclavagista com especial ênfase para o sofrimento dos escravos transportados na lógica transatlântica do comércio negreiro. A ideia subjacente é sempre transmitir ao leitor, com o máximo de rigor, a mensagem que se pretende difundir, nos exemplos dados, subjacente ao sofrimento humano gerado por situações de profunda injustiça política e social e este será um traço que o autor mantém ao longo de toda a sua obra. Nas suas fiç̧ões, Ndongo conta mais do que a história e a cultura da Guiné Equatorial, ele tenta abranger todos os desafios, conquistas e perdas sofridas por povos que ainda não alcançaram a almejada estabilidade que Ihes permita a felicidade nas suas próprias terras. 
Se em Las tinieblas de tu memoria negra era visível esse enfoque na intenção de ficcionar em torno de uma realidade confrangedora e coactiva, focando o período de transição do colonialismo para a autodeterminação, em Los poderes de la tempestad, o autor situa-se na ditadura de Francisco Macías, criando toda uma trama ficcional que reporta diretamente a fatos ocorridos naqueles tempos. Sem referência cronológica, mas com referências textuais que nos remetem para determinados fatos históricos, o autor consegue engendrar toda uma narrativa. Na narração são explorados alguns símbolos da mudança como, por exemplo, a toponímia urbana, a criação de novas barreiras à mobilidade das pessoas dentro do perímetro citadino, a transformação rápida da sociedade, a vivência com base na intimidação e no medo, espelhados em pequenos elementos que vão povoando a narrativa e que, de quando em quando, fazem o leitor voltar à origem de tudo, ao começo da ditadura, ao início da reafricanização dos espíritos tão magistralmente simbolizada no bastão que acompanha o presidente como testemunho de um poder que se quer afirmar ancestral ou, pelo menos, chegado através do reconhecimento dos poderes tradicionais. Revelase, assim, uma clara e abusiva tomada de um símbolo que aqui reveste apenas um valor que se quer afirmar (a tradição), em nome da qual se pode perseguir, se pode matar, em nome da qual se promete luta incansável não contra os opositores, mas contra os símbolos de esses poderes outros que mais não significam que a opressão, o colonialismo, a religião outra (o catolicismo), o imperialismo, a imposição de uma modernização estrangeira... Assim sendo, este segundo romance de Ndongo continua a tradição do primeiro, contando a história e as estórias que povoam um povo atormentado na sua busca da felicidade. Será esse o exercício de cidadania de Donato Ndongo enquanto escritor?

Apesar de referir inúmeras vezes que acredita que o exercício governamental e a literatura são incompatíveis e que a sua escolha primária seria sempre a literatura, Donato Ndongo nunca descartou o seu papel enquanto cidadão activo no seio de uma sociedade que quer ver transformada. Reconhecendo as limitações da literatura nas sociedades africanas, por falta da literacia necessária para a criação de um público com alguma capacidade crítica, deixa, contudo, uma via aberta para a intervenção social do escritor que seria intrínseca a essas próprias sociedades. Para tal, lembra o papel do griot, contando a história da comunidade, denunciando os seus males, anunciando caminhos e soluções, contribuindo para a moralização da sociedade. Deste modo, vê o seu papel, enquanto escritor e cidadão, como aquele que produz arte e deve entreter, mas que, sobretudo, aponta o caminho ou denuncia o que está errado. Herdeiro de uma tradição ancestral, Ndongo quer afirmar-se como um contador de histórias, uma pessoa que em determinado contexto social assumiu esse papel, como aquele que por uma qualquer razão tem esse dom e deve dele fazer uso. Reportandose à sua cultura mãe fala de uma arte criada com um propósito, explicando que na sua sociedade a arte pela arte nunca existiu, há que dar-Ihe um significado e um objectivo.

Embora assim seja, admite que isto não significa que o valor estético não tenha de ser intrínseco à obra literária, sendo muito importante na consolidação da mensagem o uso de recursos como a ironia, os jogos de palavras, as técnicas narrativas associadas à criação das personagens, do narrador e a própria forma de contar. Ancorando a sua obra na realidade que pretende divulgar e sobre a qual quer 
actuar, constrói ficções enriquecidas pelo domínio das ferramentas estéticas que estão ao seu dispor e, como afirma o próprio autor, é preciso ter talento para se dizer exactamente aquilo que se pretende dizer. A falta de um público culto ou familiarizado suficientemente com a escrita, obriga o escritor a procurar formas de expressão que permitam passar toda a duplicidade que uma palavra pode ter, toda a metáfora que uma descrição possa conter, todavia de um modo que se adapte à sua leitura do texto. Assim, Donato Ndongo refere a incorporação da literatura oral, com a sua tradicional repetição, dizendo a mesma coisa de diferentes maneiras ao longo da mesma narrativa e tudo porque se prepara o texto para ser lido, mas também para ser escutado, porque em sociedades de baixa literacia é sempre possível que haja um intermediário a contar a história.

Deste modo, o autor reitera que se a literatura é arte e como tal tem de ser bela, igualmente, deverá ser útil para que sirva as necessidades dos povos e detenha um verdadeiro papel social e cultural, contra todas as injustiças que condenam muitos ao subdesenvolvimento e à miséria. Coloca, pois, ao lado da estética e da arte, o serviço aos povos na criação de uma mensagem audível que possa conduzir à transformação social, à mudança de mentalidade, a uma cultura de participação e desenvolvimento, em detrimento do deleite solitário de um leitor ocioso e egoísta que não pretende nada mais que o gozo estético. Assume, portanto, como objectivo na sua criação literária o exortar à ação e, quando tal não aconteça, o mobilizar mesmo que passivamente para a descoberta de uma nova realidade ou de uma verdade antiga até então e por qualquer motivo ocultada. De facto, a obra de Donato Ndongo é um exercício de cidadania, difícil de determinar se primeiro começa a intervenção social ou a criação artística. Lembremos que a sua primeira ficção é engendrada a partir de um relato jornalístico do real, recordemos que começa por cursar jornalismo e paralelamente a interessar-se por literatura. No entanto, algo é indiscutível, Donato Ndongo sentia a urgência de escrever, a necessidade de registar algo novo e específico e decidiu converter esse seu talento não só numa escrita do real como numa escrita da ficção, permissiva face a todas as utopias que devem ser sonhadas para poderem ser postas como alternativas a um mundo, por vezes, atroz que vitima os mais desprotegidos.

Cremos que no caso do autor em estudo, arte e cidadania activa caminharam de mãos dadas, se, por um lado, nos pode parecer que a arte foi colocada ao serviço de um objectivo pragmático, por outro lado, essa vontade de agir sobre a sociedade ficou contida numa expressão artística profunda, em que o escritor se tem claramente distinguido. Mais do que saber se o escritor precede o cidadão ou vice-versa, é importante sublinhar o papel social que o próprio autor reconhece na sua obra, enquanto alguém que escreve para o mundo para agir sobre este, contribuir da forma que sabe para a mudança, fazer do leitor passivo, um protagonista da transformação da sociedade, mais alerta, mais consciente e, sobretudo, pró-activo. Como começámos por citar no início deste ensaio, o uso do poder da palavra, colocado ao serviço de uma arte que se quer integrada na sociedade e que permita a antecipação de alternativas, é o que tem caracterizado a obra deste escritor, cidadão interventivo, defensor dos valores humanistas e universalistas, querendo passar essa mensagem a todos aqueles que o leiam. 


\section{Escritas com identidade e memória}

[...] lenguas originariamente europeas [...] que las hemos adoptado como instrumentos de liberación y de proyección hacia la universalidad; las hemos hecho nuestras, tan nuestras como nuestras nativas africanas, y las hemos transformado, las estamos vivificando, enriqueciéndolas [...] para dar testimonio de nuestro tiempo y conservar la memoria. (NDONGO, 2010, p. 23)

É o próprio autor que declara que a sua escrita está marcada pela busca das marcas de identidade equatoguineense, porque há que saber quem se é e porque se é. Mas que identidade é esta que se pode encontrar através da escrita e da leitura numa língua, originariamente alienígena, resultante de um encontro de culturas que promoveu não só uma colonização política, como a colonização da palavra, da memória e até do imaginário (referindo-se este ao passado, ao presente ou ao futuro)? Será que estamos presente o que Ladry-Wilfrid Miampika designou como a tensão entre a palavra e a memória que tem constituído um espaço de exploração identitária e de reflexão histórica e literária (MIAMPIKA, 2010, p. 10)? Ndongo responde-nos com a sua própria obra literária, apropriando-se de um idioma que, actualmente, é a língua veicular entre todas as etnias no seu país, expondo a sua transformação, a sua transterritorialização, a sua quota-parte de participação num sistema cultural completamente autónomo de todos os outros com quem partilha essa mesma língua. Esse espanhol, falado com características e regionalismos típicos da Guiné Equatorial, constitui também uma parte substancial da identidade e da memória locais, não só como veículo de transmissão de uma verdade, de uma cultura, bem como, de pertença intrínseca a esse mesmo sistema cultural, mesmo que tenha surgido por imposição e através de meios, que mais do que persuasivos, foram, inúmeras vezes, violentos. Deste modo, não é de estranhar que o autor tome esta língua como aquela em que poderá narrar as histórias do seu povo, as histórias do seu continente, as memórias, os diálogos, os encontros e desencontros históricos e culturais de que o seu país foi palco, de que o país em que hoje vive é cenário...

Aliás, o autor não se furta a esta convivência entre os relatos ficcionais e a sua própria experiência biográfica e o seu percurso enquanto homem de cultura africana e hispânica. Na entrevista que concedeu a Michael Ugarte, anteriormente citada, deixa explicito que toda a literatura tem algo de autobiográfico e que a sua não é excepção, considerando que tudo o que preenche a vida de cada um pode ser tornado literatura, abarcando pensamentos, imagens, sensações. De todas as formas refuta que os seus romances se consignem unicamente à sua memória enquanto indivíduo e à sua experiência vivencial directa, explicando como se pode inspirar em factos exteriores ou na partilha de experiências com outros. No fundo, a memória que pretende relatar é mais abrangente e formada por várias aproximações à realidade, ou seja, quando escreve a sua ficção o que está em jogo são um conjunto de sensações e experiências, vivenciadas directa ou indirectamente, mas que the parecem que urge contar. Talvez seja nesse sentido que Michael Ugarte, num seu artigo (UGARTE, 2004, p. 177-178), refira que Ndongo fornece ao leitor elementos que levam à compreensão de vozes que foram sendo silenciadas, caladas por que subalternas, numa mudez ruidosa, por ser contrária à vontade dessas vozes que queriam gritar em vez de calar a sua dor. 
Assim, parece que o desígnio do autor é abarcar uma multiplicidade de vozes e representá-las ao longo da narrativa, seja através das suas personagens, seja através dos jogos que faz com o narrador que pode alternar ou encetar um "diálogo" permanente com as personagens, como se fosse um alter-ego falando com o ego, demonstrando as dúvidas, os anseios, os paradoxos, os pensamentos, por vezes divergentes, que cada ação pode enfrentar, no fundo, o conflito interno que cada atitude de uma personagem pode gerar no tempo em que decorre a ação ou transcorrido esse presente, numa fase em que o que está em cogitação já é a consequência da ação que, amiúde, parece inofensiva e sem qualquer simbolismo, apesar de não o ser. Os três romances publicados, Las tinieblas de tu memoria negra, Los poderes de la tempestad e El metro, todos têm abordagens deste tipo. A duplicidade, no primeiro caso, já que o romance se passa na transição do colonialismo para a autodeterminação, portanto do confronto de duas situaç̧ões aparentemente opostas, em que parece existir alguma unidade numa e noutra posição. A multiplicidade no caso dos dois últimos, já focando o período pós-colonial em que pululam expectativas e aproximações divergentes a uma mesma situação. Integrandose os dois primeiros títulos numa trilogia que Ndongo pretende publicar, faltando, como último título Hijos de la tribo, que o autor já anunciou, percebemos que há um enfoque específico quanto à memória e identidade comuns na Guiné Equatorial, ou seja, há um resgatar de memórias, confrontando os registos históricos coloniais, positivados na escrita, com os registos orais, também históricos, contando todo o percurso de uma etnia, de uma tribo, de um clã, produzindo uma abordagem múltipla ao discurso que se quer feito em diálogo.

Assumindo os desafios do presente, o autor tenta articular as vozes silenciadas que experimentaram as realidades traumáticas que narra e, em simultâneo, relatar uma memória que sirva como desafio à indiferença com que as questões da Guiné Equatorial têm sido tratadas nos fora internacionais ou pelos países que, habitualmente, se declaram defensores da liberdade e da democracia. Ao invés, de justificar todos os comportamentos, sejam estes identificados com assunções de modernidade ou tradição, demonstra como o diálogo cultural é o caminho mais profícuo e como certas tradições, apesar de reiteradas, deixaram de fazer sentido, porque atentam contra as liberdades individuais, ou como certos aspectos da modernidade não fazem sentido em culturas que gizaram percursos próprios e diferenciados dos países que propalam uma massificação cultural em nome do desenvolvimento e da modernização social. É percorrendo este caminho que Donato Ndongo nos expõe a forma como, apesar da descolonização política, ainda subsiste um imaginário e uma memória colonizadas, por uma presença que se apropriou de conceitos que, sendo hoje extensíveis a todas as sociedades como o objectivo de desenvolvimento e bem-estar das populações, parecem ter-se mantido propriedade de determinadas culturas ou povos. Ao reescrever na sua ficção partes da histórica africana o que o autor faz é contribuir para a devolução da história a uma parte importante dos seus protagonistas, que nos aparecem não como sujeitos passivos ou objectos da história colonial e pós-colonial emanada dos grandes centros de conhecimento ocidentais, mas como sujeitos ativos e preparados para os desafios do presente. Esse é o grande contributo que Ndongo presta à literatura do seu país, 
mostrando como uma escrita carregada de memória e apta a discutir a identidade pode afirmar-se por si só. A curiosidade do seu trabalho é que Donato Ndongo faz tudo isto a partir de uma escrita de exílio, da sua condição de emigrado forçado noutro país, o que não deixa de ser notório na construção da sua obra: paralelamente a uma ligação forte ao país natal, existe uma visão em simultâneo endógena do passado e exógena do presente, ou seja, interioridade e exterioridade comunicam-se num complexo resultado de perda e de luta, como que numa saudade que ainda dá forças para continuar a procurar a reconquista desse espaço num possível regresso. Estamos, portanto, perante um exílio literário, resultante do exílio do escritor, mas que ao invés do apartar da sua origem, o parece ligar a uma trama que faz com que alguns aspectos pareçam ficar cristalizados e sejam presença permanente e extensiva a toda a sua ficção.

\title{
Exílio real e ficcional?
}

\begin{abstract}
Todos confiaban en que en Europa encontrarían remedio de todos los males, la seguridad y la felicidad. Pero llamaba la atención que ninguno pensara establecerse en aquellas tierras soñadas: emigraban sólo por el tiempo necesario para luego situarse en el propio país, el lapso que tardaran en ahorrar lo suficiente para colmar sus aspiraciones o cubrir sus necesidades, casarse, construir una casa en la aldea natal, emprender un pequeño negocio, completar los estudios, esperar el fin de la guerra o a que amainase la tormenta política. (NDONGO, 2007, p. 325).
\end{abstract}

Donato Ndongo abordou a questão do exílio tanto do ponto de vista ensaístico como ficcional, sendo uma das suas mais perenes preocupações e que é perfeitamente legível ao longo da sua obra. Nas suas palavras, enquanto entrevistado, refere que o problema não seria a imigração, mas a emigração, elegendo como ponto-chave para a discussão os factores que levam alguém a migrar, arriscando a sua própria vida. Apresenta como factores determinantes os problemas diários da população que se vê confrontada com a pobreza, o subdesenvolvimento, a guerra e a repressão que conduzem ao êxodo de muitos. Daí que coloque o acento tónico nas dificuldades que as pessoas enfrentam para ultrapassar o Sara a pé, para colocarem-se em frágeis embarcações e tentarem transpor o Mediterrâneo, e na angústia que trazem nos corações os homens e mulheres que arriscam desta forma as suas vidas, não se furtando ao caso das mulheres grávidas que entram nesta aventura. O interessante é que o autor não se confina à realidade do seu próprio país, buscando continuidades entre as situações dos povos que se vêem confrontados com a urgência de abandonar os seus países.

Deste modo, compreende-se que no seu romance, o último que publicou, $E I$ metro, a personagem principal seja um imigrante em Espanha cuja identidade se ancora, partindo do mais geral para o mais particular, no facto de ser africano, francófono, camaronês, de etnia fang, ou seja, o seu destino de distanciamento face à sua cultura pode ser visto à luz de qualquer uma destas identidades que, afinal, coabitam na mesma personagem. O protagonista começa a sua longa etapa em direcção ao exílio com uma migração no interior do seu país, indo depois confrontando-se com realidades, paulatinamente mais latas, e descobrindo as várias 
pertenças que tem. Se na capital dos Camarões, Yaoundé, é um fang por oposição aos membros das outras etnias, no norte de África é simplesmente alguém da África negra e francófono, por oposição às personagens de outras origens, quando chega a Espanha torna-se simplesmente num africano por oposição ao europeu. $\mathrm{O}$ que somos levados a percorrer, neste romance, é uma sucessão de exílios que começam com a saída da terra natal e com o afastamento do seu clã de origem, neste caso, fomentado por uma fuga a uma imposição de uma tradição que se revela já desarticulada face à realidade actual. Assim, apesar de o relato começar no presente da personagem principal, a verdade é que através do flash back vai recuperar todo o passado que resgata o seu tempo e espaço de origem, como se o presente fosse uma função deste, isto é, um tempo em suspensão à espera de ser validado pelo passado e pelas suas razões que acabam por justificar esse presente.

Segundo alguns autores, estas serão uma das características mais típicas da literatura de exílio, que levam a uma construção do presente com base nas perdas, nas nostalgias, nos horizontes fechados, isto é, na ausência do espaço real em termos geográficos que se torna espaço psicológico e na introdução de uma relação causa/efeito directa entre passado e presente, em que um compete na sua importância com o outro e em que o presente parece ser apenas uma plataforma para o regresso ao espaço do passado. A narrativa de origem para além de condicionar o presente, pode mesmo desestabilizá-lo, porque, por vezes, indicia a procura por uma pertença identitária, sobretudo se se trata de um meio hostil ao migrante, que busca localizar-se face ao presente e ao passado. No caso de Ndongo, é perceptível a sua sensação de estrangeiro face à sua cultura e país de origem, enquanto escritor e cidadão, apesar de viver em Espanha há muitos anos e aí ter constituído família, e esse seu traço biográfico tem sido transposto para a sua obra literária. Se em El metro - vemos acontecer, também em Las tinieblas de tu memoria negra existe o questionamento do exílio cultural forçado aos povos africanos que tinham de aderir aos valores propagados pela colonização europeia, em que é exposto o dilema do biculturalismo e a forma como este foi imposto, e em Los poderes de la tempestad com o regresso da personagem principal ao seu país de origem, confrontando-se com a perda da sua família europeia e com o facto de quase ser um estrangeiro no local onde nasceu.

Em qualquer um dos três romances existe um relato migratório, uma viagem de partida ou de regresso, isto é, são criados momentos dramáticos em torno deste aproximar e/ou apartar do local de origem, num jogo em que tomam parte o espaço geográfico (físico e real) e o espaço psicológico (memória e interiorização do espaço físico, criação do indivíduo). Alias, o exílio aparece como uma experiência partilhada por diferentes indivíduos, com as mesmas razões umas vezes e com motivos diferentes noutras, mas o importante é que, de alguma maneira, todos se sentem forçados a partir, com a ideia de mais tarde regressar, tal como no trecho que citamos no início deste ponto. Assim, o relato da viagem, a situação legal, as fronteiras geográficas, sociais e psicológicas são expostas como um todo, num complexo processo de revelação da problemática do exílio, fortemente ancorada numa realidade colonial e pós-colonial que deixa poucas ou nenhumas opções aos africanos. Estas saídas, não desejadas à partida, precipitam a sensação de questionamento da própria 
identidade ou de ausência identitária, daí o papel quase inquiridor dos narradores de Ndongo, visando estabelecer essa mesma identidade viva, embora controversa. Como africano, como equatoguineense, como fang, como exilado, Donato Ndongo sentiu directa ou indirectamente as vivências que recriou em ficção, dando-Ihes um cunho criativo que as afasta da realidade, é certo, mas tentando mantê-las como conteúdo vivo e como mensagem final da sua obra, combinando o seu exílio real com o exílio ficcional das suas personagens, numa complexa composição de obras que podemos identificar como pertencentes a uma literatura de exílio.

\title{
De Las tinieblas a EI metro: encontros e desencontros
}

\begin{abstract}
Se había construido una casa grande de cemento con techo de cinc que se distinguía desde lejos como un inequívoco signo de distinción, emergiendo refulgente de entre las construcciones de barro y nipa, con la frondosa naturaleza alrededor. Había sido el primero en cavar un pozo ciego en el patio, disimulado por una caseta que nadie que no estuviera en el secreto de las cosas sabía para qué servía, para evitar que defecáramos bajo los cafetales mientras las gallinas picoteaban en los excrementos; había sido uno de los primeros, si no el primero, de la comarca, en abrir una finca de café, símbolo de un nuevo tiempo que anunciaba la modernidad. (NDONGO, 2000, p. 21-22).
\end{abstract}

Las tinieblas de tu memoria negra e El metro são respectivamente o primeiro e o último romances de Donato Ndongo. Ambos resultam de reaç̧ões do autor a dois momentos directamente ligados à sua reflexão sobre as identidades africanas e o papel do outro nas culturas em interacção, neste caso a africana e a europeia. Se Las tinieblas... nasce com o título de um verso de Senghor, integrado num dos poemas de Chants d'ombre, em que é evidente a procura de uma identidade racial, cultural, linguística e existencial, ainda num contexto colonial e de transição para a autodeterminação, El metro decorre da própria experiência do autor passada no metro de Madrid quando viajava só com um casal espanhol na mesma carruagem, numa hora avançada da noite, tendo verificado o quanto foi observado e encarado como o outro, apesar da sua longa vivência em Espanha, o que o levou a repensar o papel do imigrante africano numa sociedade europeia. Em ambos os casos, os protagonistas são do género masculino, no primeiro romance, alguém que nunca chega a ser identificado com um nome, no último romance, um jovem, Lambert Obama Ondo. Ambas as personagens principais são descendentes de famílias importantes no contexto das sociedades tradicionais africanas e têm no seio da sua família um representante da cultura tradicional, que se torna no herói da narrativa, e outro membro que representa o exemplo máximo de assimilação ao colonizador; ambos são fang e, apesar de partilhar a etnia, são originários de países diferentes, um da Guiné Equatorial outro dos Camarões, fazendo sobressair a artificial divisão geopolítica que raramente correspondeu a uma divisão identitária; os dois empreendem uma viagem em direç̧ão a Espanha, o primeiro ainda menino e levado pelos missionários para seguir os seus estudos, o segundo já adulto num acto voluntário de fuga à situação no seu país; na verdade, ambos enfrentando uma mesma necessidade apesar do afastamento temporal da acção: a necessidade do êxodo que os coloca numa situação de exílio. 
Neste aspecto e não sendo ambos os romances auto-biográficos, até porque a narrativa se afasta em diversos aspectos, são fruto da experiência directa e indirecta do autor, tal como ele o refere em entrevista, pois também ele é de etnia fang, também ele teve de sair do seu país, protagonizando um longo exílio, também ele passou por uma viagem em que o levaram e outra em que teve de sair devido a perseguição política, atravessando fronteiras por via terrestre, isto é, existem elementos que ligam directamente o autor a algumas características das personagens e a alguns momentos da narrativa, se bem que numa perspectiva diferente, indo a ficção muito para além de uma simples projeção da realidade, transposta para uma linguagem bela. Há todo um trabalho de construção da narrativa e de diversificação das perspectivas das personagens que o atesta. Os dois romances apresentam como fundo constante o diálogo entre tradição e modernidade nas sociedades coloniais que se projecta e afirma nas sociedades pós-coloniais, levantando agora outras problemáticas ligadas à construção identitária que acaba por surgir no seio de conflitos e negociações constantes entre as culturas africanas, no caso das personagens principais, da cultura fang e a cultura do colonizador que, no primeiro caso, coincide com a cultura do país e emigração e no segundo não coincide. Ambos os romances começam no presente para se projectarem para o passado numa procura das razões do "agora", como se o tempo presente fosse um espaço de mediação entre o passado e o objectivo que se pretende alcançar no futuro, recorrendo ao flash back, que inicia o leitor na viagem física e psicológica das personagens.

Ao narrador atribui-se a capacidade de diálogo com as personagens ou do seu conhecimento pleno, em Las tinieblas... num diálogo constante entre a primeira e a segunda pessoas, em El metro com uma multiplicidade de vozes a que um narrador omnisciente acede até ao pensamento, às dúvidas. Nos dois romances gerando um diálogo com o próprio leitor que se vê catapultado para a análise das dimensões psicológicas das personagens com mais protagonismo na narrativa. Esta construção narrativa e a atribuição deste papel ao narrador espelha, em parte, a tradição de uma narrativa oral, em que os apartes do narrador, as interjeições ao ouvinte são parte da técnica narrativa. Igualmente a interpelação directa ao leitor poderá ter essa raiz, com a repetição de frases que se tornam chave na construção da memória das personagens e que sobressaem na narrativa para o leitor perceber o quão profundamente estão enraizadas, cumprindo um papel simbólico no decorrer de toda a diegese porque traduzem directamente comportamentos ou concepções culturais, isto é, modos de vida e expectativas perfeitamente enraizadas naquela sociedade. A técnica de narrativa utilizada permite ao leitor acompanhar a procura pela "autenticidade" identitária das personagens e, em simultâneo, recriar uma série de acontecimentos e situações que, para além de traçaram o quadro da memória, explicam por si o dilema enfrentado pelas personagens que não é mais do que a procura de uma identidade que Ihes seja fiel, entre uma autenticidade que se quer afirmar e uma hibridização que está patente em vários aspectos simbólicos da narrativa. Nas duas histórias encontramos essa duplicidade de personalidades, uma encurralada na tradição e outra empurrada para uma suposta modernidade, sendo que o sujeito da ação vai sofrendo uma transculturação que resulta no questionamento da sua suposta identidade, 
resultando na equação de uma notória mestiçagem cultural ou hibridização, consoante se prefira chamar-lhe.

A tensão entre tradição e modernidade, presente nos dois romances, transferese a vários níveis da obra, por exemplo, reflectindo-se na tensão entre oralidade e escrita, na formalidade que a segunda expressão assume face à primeira, na importância atribuída às cartas, aos documentos, como se o conhecimento escrito tivesse sido (como foi) sacralizado face ao conhecimento oral que seria pertença apenas dos que não conheciam uma técnica que, em si, foi assumida como símbolo de civilização (esquecendo-se os colonizadores das elevadas taxas de analfabetismo existentes nos seus próprios países) ${ }^{2}$. Também nesta tensão se encaixa a alternância dos discursos, de quem tem o poder ou o direito de usar da palavra, de a converter de uma forma a outra, reflectindo todos os jogos de poder subjacentes ao aspecto político, de domínio sobre a sociedade e de controlo sobre a estada do outro em determinado território, e ao aspecto social, em que o silêncio e a fala estão associados ao papel social que cada um desempenha e à hierarquia em presença. Aliás, o espaço social será determinante na construção da narrativa, pois igualmente este nos transporta numa viagem que não se limita à transposição dos espaços geográficos, e a importância dada a este elemento reforça os aspectos de pressão que existem entre os espaços modernizados e aqueles que parecem ter-se mantido fiéis à tradição.

Outra questão não menos importante é que a migração, nas duas personagens principais destes romances, dá-se em vários campos, isto é, se se deslocam no espaço, também se deslocam em termos de enquadramento social, daí que sejam migrantes a vários níveis, ocupando em cada espaço sócio-geográfico um determinado papel que nem sempre é o de subordinado e desprotegido... é caso para lembrarmos que Lambert Obama Ondo (em El metro) partilha com o leitor a sua posição, enquanto descendente de uma família aristocrática africana, o que o protagonista da narrativa de Las tinieblas... também nos dá a entender, mas de uma outra forma, pois reportase ao seu tempo de infância e de recordação. A verosimilitude da narrativa é assegurada, ultrapassando as tensões geradas pelo confronto memória/presente, tradição/modernidade, espaço rural/espaço urbano, África/Europa, através de factos que são fornecidos empiricamente ao leitor que passa não só a entender os aparentes paradoxos como a avaliá-los no contexto. O próprio diálogo com o leitor potencia esta transposição da realidade para a fiç̧ão e vice-versa, transformando a leitura numa eventual experiência do leitor (no sentido da fiç̧ão para a realidade) e num repensar dos factos jornalísticos ou experimentados acerca daquela realidade (no sentido da realidade para a ficção).

A assunção da tradução, para o espanhol (no texto original) ou para a língua de edição, de todas as línguas faladas durante a narrativa, sejam estas africanas ou europeias (caso do francês e do espanhol) elimina os possíveis traços que poderiam reportar o leitor para o domínio do exótico, aproximando-o, assim, do texto porque é escrito numa língua que domina e em que há o encontro de diversas línguas (todas

\footnotetext{
${ }^{2}$ Relativamente a esta tensão entre escrita e oralidade de demonstrando a sua antiguidade, Lola Aponte Ramos compara a personagem Lambert Obama Ondo com Platão, em que o último converte em texto escrito os ensinamentos de Sócrates que lhe foram passados através do discurso oral. Vide Ramos (2010, p. 155-167).
} 
outras na sua relação directa e que pode implicar que não sejam entendidas no decorrer da narrativa) mas que aparecem equiparadas a uma mesma dignidade, enquanto instrumento de comunicação. Contudo, a questão linguística é habilmente explorada de maneira a ir muito para além deste aspecto, sendo transposta para a problemática identitária: porque se recorre a uma língua alienígena quando existem outras intrínsecas às culturas locais? Como as línguas outrora importadas se transformam num facto de construção nacional e no único meio para pessoas de origem étnica diferente se comunicarem? Qual o peso cultural, logo identitário, da apropriação desses mesmos idiomas e da sua transformação e acomodação às culturas locais? Estas são algumas questões que naturalmente surgem ao longo da narrativa, interpelando o leitor para a sua reflexão e percepção, mostrando como uma língua, outrora emprestada, por imperativos diversos, mormente políticos e sociais, baseados num colonialismo que queria tornar estes territórios outros em apêndices da metrópole, se pôde tornar no veículo de expressão privilegiada de povos que originariamente teriam outras línguas e como esta atravessa todos os sectores das sociedades pós-coloniais, inclusivamente revelando-se na maior parte da criação literária, que é feita em línguas transterritorializadas.

A função social destes romances é proporcionada pela relação que consegue estabelecer entre o leitor e a narrativa, ou seja, pela leitura pró-ativa que é capaz de estimular. Alertando para a diversidade dos mundos em interacção, o leitor vai viajando com as personagens principais, conhecendo todos os pormenores importantes para a construção da sua personalidade, logo para a afirmação de uma determinada identidade e é na transmissão da multiculturalidade, associada às possibilidades de interculturalidade e de transculturalidade, que o autor passa a sua mensagem, alicerçada no diálogo entre culturas que, naturalmente, sucederia a um confronto de culturas. Na construção destas obras, sente-se a preocupação do autor no sentido de contextualizar as obras, de modo a torná-las trans-sistémicas, ou seja, de modo a que sejam entendíveis numa visão ampla do sistema cultural dinâmico que é sensível aos contactos entre culturas mais ou menos forçados. $O$ peso dado a este aspecto prendese directamente com a leitura dos textos que, lembremos, são editados em Espanha, portanto, num contexto de cultura ocidental, diverso da origem das personagens $\mathrm{e}$, no fundo, do princípio da narrativa. Há a intenção de abrir a interpretação dos textos e torná-la acessível a todos os que o pretendam ler, independentemente da sua própria experiência cultural. Assim, se, por exemplo, cada personagem parece incarnar um segmento social específico, toda a simbologia e discurso são trabalhados de forma suficientemente aberta para ser acessível, mesmo aos que nunca tenham convivido com nenhum indivíduo daí originário. Com um trabalho notável ao nível da narrativa, o que Donato Ndongo faz é permitir a reescritura e a re-leitura de uma história em que o africano se torna sujeito activo e em que a sua memória, mesmo sendo oral, contribui para a reescritura desse mesmo passado, memória comum que resulta numa identidade gizada a partir de encontros e de desencontros.

Se o exílio real de Ndongo Ihe tem permitido observar com alguma exterioridade o que se tem passado com África e os africanos, em geral, e com os equatoguineenses, em particular, a verdade é que a sua própria identidade e cultura são profundamente africanas e que se denota uma vivência interiorizada destas na sua 
escrita. A saudade, o apego a essa realidade estão lá, a dimensão psicológica do dilema entre aceitar uma ou outra herança cultural ou coordenar as duas, numa vivência perfeitamente intrínseca do desafio da construção identitária que é muito perceptível. Deste modo, podemos dizer que, por reflectir tanto a identidade a partir de situações que implicam o exílio e o apartar da origem, Donato Ndongo posiciona-se numa escrita que pode ser considerada de exílio, mas que ultrapassa a sua própria experiência pessoal e que se enriquece com outras tantas experiências e trocas culturais de que é sujeito indirecto ou passivo. Apesar de ter produzido uma literatura de exílio, Donato Ndongo revela uma africanidade profunda, não só pelos valores que invoca e as influências que colhe, como pela forma como narra as estórias como pelo seu conteúdo, em que fição e realidade se encontram, entrelaçando-se e dando origem a belos textos, repletos de significado e de uma mensagem, para serem questionados, em suma, escreve uma obra de entretenimento e prazer, é certo, mas também de reflexão.

\section{Referências}

COSTA, Cátia Miriam. El metro: la llegada al puerto de destino. Trad. de Josep Maria Perlasia. Oráfrica, n. 6, Abril 2010, p. 193-209

CREUS, Jacint (Coord.). De Boca en Boca: Estudios de Literatura Oral de Guinea Ecuatorial. Vic: CEIBA Ediciones, 2004

JAUSS, Hans Robert. A Literatura como Provocação: História da literatura como provocação literária. 2. ed. Lisboa: Vega, 2003.

MIAMPIKA, Landry-Wilfrid. La palabra y la memoria: Guinea Ecuatorial 25 años después (ensayo, poesía, relatos, teatro). Madrid: Editorial Verbum, 2010.

MIAMPIKA, Landry-Wilfred. La palabra y la memoria en Guinea Ecuatorial: un cuarto de siglo de travesía. In: MIAMPIKA, Landry-Wilfrid. La palabra y la memoria: Guinea Ecuatorial 25 años después (ensayo, poesía, relatos, teatro). Madrid: Editorial Verbum, 2010, p. 9-16.

NERÍN, Gustau. La literatura guinenana desde el punto de vista editorial. In: MIAMPIKA, Landry-Wilfrid; ARROYO, Patricia (Eds.). De Guinea Ecuatorial a las literaturas Hispanoafricanas. Madrid: Editorial Verbum, 2010, p. 299-305.

NDONGO, Donato. La literatura de Guinea Ecuatorial: 25 años después. In: MIAMPIKA, Landry-Wilfrid; ARROYO, Patricia (Eds.). De Guinea Ecuatorial a las literaturas Hispanoafricanas. Madrid: Editorial Verbum, 2010, p. 19-37.

El metro. Barcelona: Ediciones del Cobre, 2007.

. Las Tinieblas de tu memoria negra. Barcelona: Ediciones del Bronce, 2000.

N'GOM, M'Bare, La literatura de expresión castellana: de una "literatura posible" a una literatura real. Etapas de un proceso de creación cultural. In: MIAMPIKA, LandryWilfrid; ARROYO, Patricia (Eds.). De Guinea Ecuatorial a las literaturas Hispanoafricanas. Madrid: Editorial Verbum, 2010, p. 23-40. 
OTABELA, Joseph-Désiré. Sueños... travesías... exílio: el itinerario de Donato NdongoBidyogo. In: MIAMPIKA, Landry-Wilfrid; ARROYO, Patricia (Eds.). De Guinea Ecuatorial a las literaturas Hispanoafricanas. Madrid: Editorial Verbum, 2010, p. 109-121.

RAMOS, Lola Aponte. Hacia uns ars poética de la epístola del migrante en el metro de Donato Ndongo. In: MIAMPIKA, Landry-Wilfrid; ARROYO, Patricia (Eds.). De Guinea Ecuatorial a las literaturas Hispanoafricanas. Madrid: Editorial Verbum, 2010, p. 155167

SOARES, Francisco. Teoria da literatura, criatividade e estrutura. Luanda: Editorial Kilombelombe, 2007

UGARTE, Michael. An Introduction to Spanish Post-Colonial Exile: The Narrative of Donato Ndongo. Arizona Journal of Hispanic Studies, 2004, v. 8, p. 177-184.

UGARTE, Michael. Interview with Donato Ndongo. Arizona Journal of Hispanic Studies, 2004, v. 8, p. 217-234.

\section{Title}

Donato Ndongo and the Literary Exile.

\section{Abstract}

The writer Donato Ndongo portrays the situation in Equatorial Guinea, his country, in which a dictatorship has become a political, social and cultural structure, and where fear dominates society and prevents intellectuals to express freely their thinking. In order to understand Ndongo's work one must understand the problem underlying the artistic production in his native country and the conditions of reception in the country where he writes and of the audiences that might reach his work. Such audiences gain a singular significance as the author is forced to publish from exile, in the country that was once the colonizer, Spain, and to work for wide ranging audiences, from cultural systems too far from that of Equatorial Guinea, and thus, with no knowledge of the specificities there existent.

\section{Keywords}

Donato Ndongo. Literary exile. Artistic production.

Recebido em 05.09.2011. Aprovado em 17.11.2011. 